\title{
Efficacy of massive oral doses of retinyl palmitate and mango (Mangifera indica L.) consumption to correct an existing vitamin A deficiency in Senegalese children
}

\author{
BY CÉCILE CARLIER ${ }^{1}$, MICHEL ETCHEPARE2, JEAN-FRANÇOIS CECCON², \\ MARIE-SOPHIE MOUREY ${ }^{1}$ AND OLIVIER AMÉDÉE-MANESME $E^{1,3}$ \\ ${ }^{1}$ Institut National de la Santé et de la Recherche Médicale (INSERM), Unité 56, \\ Hôpital de Bicêtre, 78 Avenue de Général Leclerc, 94275 Le Kremlin-Bicêtre, France \\ ${ }^{2}$ Organisme de Recherche sur l'Alimentation et la Nutrition Africaines (ORANA), \\ 39 boulevard Pasteur, BP 2089, Dakar, Sénégal \\ ${ }^{3}$ Association de Recherche en Vitaminologie Pédiatrique (ARVP), II Parc Alexandre Dumas, \\ Marly le Roi, 78160, France
}

(Received 7 February 199I-Accepted 19 September 199I)

\begin{abstract}
Administration of large oral doses of retinyl palmitate has become the most widely practised vitamin A deficiency prevention strategy in developing countries. We conducted a follow-up study among 220 Senegalese children aged 2-7 years suffering from moderate undernutrition to determine the efficacy of vitamin A treatment on their vitamin A status assessed by biochemical and cytological (impression cytology with transfer) methods. The first examination $(T=0 \mathrm{~m}$ [onth]) was carried out during April 1989, before the mango (Mangifera indica $L$, ) harvest. The second examination $(T=2 \mathrm{~m}$ ) was carried out 2 months after vitamin A treatment during June 1989 when ripe mangoes become widely available. Conjunctival cells of the eyes of the children with or without ocular inflammation were responsive to vitamin $A$ administration $(P<0.01)$. There was a significant increase $(P<0.001)$ in mean serum retinol and $\beta$-carotene levels between $T=0 \mathrm{~m}$ and $T=2 \mathrm{~m}$. Mean serum retinol-binding protein (RBP) and transthyretin (TTR) levels did not differ significantly $(P>0.05)$ at $T=0 \mathrm{~m}$ and $T=2 \mathrm{~m}$. Despite the intake of vitamin $A, 54 \%$ of the children who had abnormal cytology at $T=0 \mathrm{~m}$ remained abnormal at $T=2 \mathrm{~m}$. This was due to inadequate levels of TTR and RBP, presumably due to the cereal diet eaten by the Senegalese population. Children with abnormal eye cytology had lower serum retinol levels than those with normal eyes at $T=0 \mathrm{~m}$, and $\beta$-carotene values did not correlate with eye cytological abnormalities at $T=0 \mathrm{~m}$. Children with normal cytology had higher serum retinol and also $\beta$-carotene levels than those with abnormal cytology after massive oral doses of vitamin $A$ and consumption of mangoes at $T=2 \mathrm{~m}$. Retinyl palmitate may, therefore, only lead to partial cytological improvement due to a lack of retinol-carrier proteins but dietary $\beta$-carotene may also be involved.
\end{abstract}

Oral retinyl palmitate: Carotenoids: Undernutrition: Impression cytology with transfer

Administration of large oral doses of retinyl palmitate to targeted, high-risk population groups has become the most widely practised vitamin A deficiency prevention strategy in developing countries (West \& Sommer, 1984). The physiological objective of periodic dosing is to maximize liver vitamin A reserves from a single large dose of retinyl palmitate, with minimum risk of toxicity (Hathcock et al. 1990). Ingested retinyl palmitate from the large, supplemental dose is absorbed through the intestine and transported to the liver where it is stored principally as retinyl palmitate. The liver contains $90 \%$ of the total body reserves of retinyl esters.

On demand, vitamin A (retinol) circulates from the liver to peripheral tissues by means 
of a specific carrier protein, the retinol-binding protein (RBP; Kanai et al. 1986). The complex RBP-retinol combines with transthyretin (TTR) in a 1:1 molar ratio and the complex is responsible for vitamin A transport to peripheral tissues (Goodman, 1984). Vitamin A deficiency usually does not occur as an isolated problem, but is often accompanied by protein-energy malnutrition (Oomen, 1954; Moore, 1957; Sommer et al. 1975). If the diet is low in protein, retinol is not released from the liver and its transport is impaired. This impairment is due to protein deficiency decreasing the hepatic biosynthesis of RBP and TTR, both of which are required for retinol transport and release from the liver (Smith et al. 1973b). Thus, hepatic reserves of vitamin A may be sufficient after a massive oral dose of retinyl palmitate but the vitamin A requirements of peripheral target tissues may not be satisfied owing to a lack of carrier proteins (RBP and TTR; Smith et al. 1973 a; Ingenbleek et al. 1975; Glover, 1983).

Cytologically, the earliest signs of vitamin A deficiency are the disappearance of goblet cells and the keratinization of the conjunctival cells of the eye. These cytological changes which indicate an insufficient peripheral supply of vitamin A to the eye at an early stage, can be detected by impression cytology with transfer (ICT; Wolbach \& Howe, 1925; Wittpenn et al. 1986; Amédée-Manesme et al. 1987, 1988a).

Previous surveys in Senegal showed that the prevalence of abnormal impression cytology and of retinol-deficient serum is high compared with that of xerophthalmia (Carlier et al. $1991 a, b)$. Retinol-deficient sera are also linked to low TTR and RBP levels (Carlier et al. $1991 \mathrm{~b}$ ). Several studies conducted in areas of endemic vitamin A deficiency in India (Wittpenn et al. 1986; Reddy et al. 1989) and in Indonesia (Natadisastra et al. 1987) showed that almost all children with abnormal cytology revert to normal after vitamin $A$ treatment. The efficacy of massive oral doses of retinyl palmitate given to deficient subjects to fulfil requirements for more than 8-12 weeks is controversial (Pereira \& Begum, 1971; Kusin et al. 1980; Thanangkul et al. 1980; Thurnham, 1991).

For this reason we conducted a follow-up study among Senegalese children aged 2-7 years suffering from moderate undernutrition. The efficacy of massive oral doses of retinyl palmitate on the vitamin A status was assessed by biochemical and cytological methods.

\section{MATERIALS AND METHODS \\ Period of the study}

The study was divided into two parts. The first examination $(T=0 \mathrm{~m})$ was carried out during April 1989, before the mango (Mangifera indica L.) harvest. The second examination $(T=2 \mathrm{~m})$ was carried out 2 months after a massive oral dose of retinyl palmitate. This is the time required to observe cytological improvement, such as the reappearance of the goblet cells (Wittpenn et al. 1986). Therefore, the second examination was conducted during June 1989 when ripe mangoes become widely available (estimated carotenoid content: $126600 \mathrm{mg}$ vitamin A activity $/ \mathrm{kg}$; Tsou et al. 1984).

\section{Study population}

Two rural villages (Gadiack and Diop N'doffene) in the groundnut belt of Senegal were randomly selected. Nearly all the children ( $n 554)$ aged $2-7$ years old in the Gadiack $(n 300)$ and the Diop N'doffene ( $n$ 254) villages were enrolled for the survey.

A team consisting of a paediatrician, a nutritionist, an ophthalmologist, a laboratory assistant, and two fieldworkers examined the 554 children and selected 220 children for the survey according to ophthalmological and anthropometrical criteria as described below.

Inclusion criteria: (1) Ophthalmological examination. All eye examinations ( $n$ 554) were carried out by a well-trained ophthalmologist in normal daylight with a portable slit-lamp 
Table 1. Analysis by impression cytology with transfer: classification of the results

\begin{tabular}{|c|c|c|c|}
\hline \multicolumn{2}{|r|}{ Criteria } & \multirow[b]{2}{*}{ Stages } & \multirow[b]{2}{*}{ Results } \\
\hline $\begin{array}{l}\text { Goblet } \\
\text { cells }\end{array}$ & $\begin{array}{l}\text { Appearance of the } \\
\text { epithelial cells }\end{array}$ & & \\
\hline $\begin{array}{l}\text { Present } \\
\text { Present }\end{array}$ & $\begin{array}{l}\text { Numerous, small, in masses } \\
\text { More small cells than } \\
\text { enlarged or separated cells }\end{array}$ & $\begin{array}{l}\text { Normal } \\
\text { Marginal (+) }\end{array}$ & Normal \\
\hline $\begin{array}{l}\text { Absent; mucin } \\
\text { spots present } \\
\text { Absent }\end{array}$ & $\begin{array}{l}\text { Enlarged and separated cells } \\
\text { more than small cells } \\
\text { Enlarged and separated cells }\end{array}$ & $\begin{array}{l}\text { Marginal (-) } \\
\text { Deficient }\end{array}$ & Abnormal \\
\hline
\end{tabular}

(Kowa SL 5). Examinations were based on the diagnostic criteria for xerophthalmia (Bitot's spots, corneal xerosis, and/or ulceration, keratomalacia; World Health Organization, 1982). None of the 554 children showed clinical signs of vitamin A deficiency.

(2) Anthropometric selection. The height and weight of each of the 554 children were recorded. As stunting is one of the major clinical signs of undernutrition observed in this rural area (Carlier et al. 1991 a) and as we have found a relationship between abnormal ICT results and stunting (Carlier \& Amédée-Manesme, 1991), children were selected on the basis of the two indicators of nutritional status (weight-for-height $(\mathrm{W} / \mathrm{H})$ and height-forage $(\mathrm{H} / \mathrm{A})$ ) which define stunting according to the guidelines of the World Health Organization (1983). There were 220 children with these two anthropometrical indicators below the conventional cut-off points of $80 \%$ of the reference median for W/A and $90 \%$ of the reference median for H/A (Waterlow, 1976) and these children were, therefore, enrolled in the survey.

(3) Follow-up selection. After 2 months, 190 children were available for re-examination. Thirty subjects were lost to follow-up for the second examination (parental refusal to allow participation or absence).

This protocol was approved by the Organisme de Recherche en Nutrition et en Alimentation Africaines Ethics Committee of ORANA and by the Senegalese Ministry of Health.

\section{Evaluation of vitamin A status by cytological and biochemical variables}

Cytological criterion: ICT. ICT was performed as previously described (Luzeau et al. 1988; Carlier et al. 1989) on the 220 children selected at $T=0$ and on the 190 children available at $T=2 \mathrm{~m}$. Both eyes were examined. The subject was scored according to the reading from the eye closest to normal. All readings were taken by a single worker using a microscope. In accordance with Natadisastra et al. (1987) and Keenum et al. (1990), enlarged and keratinized epithelial cells and the loss of goblet cells were considered to be abnormal, and sheets of small epithelial cells and the presence of goblet cells were scored as normal (Table 1). Abnormal readings were classified into one of three groups: marginal $(+)$ marginal $(-)$ or deficient (Table 1).

Blood samples. Capillary blood was drawn into a microcontainer (Becton Dickinson Microtainer ${ }^{\vec{R}}$, Franklin Lakes, NJ) from 185 children participating in the two examinations ( $T=0 \mathrm{~m}$ and $T=2 \mathrm{~m}$ ). It was not possible to get blood samples from thirty-five of the children due to parental refusal. Blood samples were stored in an insulated cool box and then centrifuged at room temperature for $10 \mathrm{~min}$ at $2000 \mathrm{~g}$. The serum was distributed into 
two plastic microtubes for the determinations of the two serum proteins (RBP, TTR) and of the vitamin $\mathrm{A}$ (retinol and $\beta$-carotene) concentrations and then frozen at $-20^{\circ}$. The samples were transported to Paris in dry ice and stored at $-20^{\circ}$ until analysed within 1 month.

TTR and RBP were determined by nephelemetry using standard rabbit serum from Behring (Fink et al. 1989). Retinol and $\beta$-carotene were analysed by reverse highperformance liquid chromatography with detection at 325 and $450 \mathrm{~nm}$ respectively. A solution $(100 \mu \mathrm{l})$ of retinyl acetate in ethanol (internal standard; $0.2 \mu \mathrm{g} / \mu \mathrm{l}$ ) was added to a $100 \mu \mathrm{l}$ serum sample. After mixing, vitamin A was extracted with $1000 \mu l n$-hexane by mixing with a Vortex mixer for $1 \mathrm{~min}$. After centrifugation $(5 \mathrm{~min}, 2000 \mathrm{~g}$ ) the organic layer was collected and was evaporated at $25^{\circ}$ in a gentle stream of nitrogen. The residue was dissolved in $250 \mu \mathrm{l}$ methanol-tetrahydrofuran $(93: 7, \mathrm{v} / \mathrm{v})$ and injected $(200 \mu \mathrm{l})$ into a Merck Lichrosorb (Darmstadt, FRG) C-18, Hypersil type H 225 column. Elution was carried out with methanol-tetrahydrofuran $(93: 7, \mathrm{v} / \mathrm{v})$ at a flow-rate of $0.8 \mathrm{ml} / \mathrm{min}$, monitored at $325 \mathrm{~nm}$ for $7 \mathrm{~min}$ and then at a flow-rate of $2.5 \mathrm{ml} / \mathrm{min}$, monitored at $450 \mathrm{~nm}$ up to $13 \mathrm{~min}$. Inter-run precision for the method was determined from ten replicate determinations of a serum pool. The mean value was for retinol $0.25(\mathrm{SD} \mathrm{0.006)} \mu \mathrm{mol} / 1$ (coefficient of variation (CV) $2.4 \%$ ) and for $\beta$-carotene 119.9 (SD 4.6 ) nmol/l (CV 3.8\%) respectively.

\section{Evaluation of ocular inflammation diseases}

During the ophthalmological examination described previously, other eye diseases including trachoma and conjunctivitis were also diagnosed (Thylefors et al. 1987).

\section{Distribution of vitamin $A$ capsules}

All the 220 selected children received orally, at $T=0 \mathrm{~m}$, one vitamin A capsule containing $110 \mathrm{mg}$ retinyl palmitate and $26.8 \mathrm{mg} \alpha$-tocopherol (World Health Organization, 1982). Provision was made for an additional dose 1 week later but without medical supervision.

\section{Statistical methods}

The statistical calculations were performed using the program STAT VIEW TM T12 $_{\text {, Brain }}$ Power, Inc., 24009 Ventura Blvd. Values are expressed as means with their standard errors of means. Student's $t$ test was used to test the differences between biochemical means and the Chi square $\left(\chi^{2}\right)$ test to assess the differences between categorical variables. All significance values reported were two-tailed, with $P<0.05$ considered statistically significant (Schwartz, 1986).

\section{RESULTS}

\section{Study population}

The age and sex distributions ( $\%$ ) of the 220 selected children were as follows: $2-3$ years $16 \cdot 8,3-5$ years $47 \cdot 7,5-7$ years $35 \cdot 4$. Of the total $44 \%$ were boys and $56 \%$ were girls.

\section{Evaluation of vitamin $A$ status}

The vitamin A status of each of the 220 children was assessed by cytological and biochemical methods.

\section{Cytological method: ICT}

Table 2 summarizes the cytological data. The subjects were scored for vitamin A deficiency by cytological analysis of the eyes, at $T=0 \mathrm{~m}$ and $T=2 \mathrm{~m}$. Each subject was further classified according to the presence or absence of ocular infections, as such infections could 
Table 2. Impression cytology with transfer $(I C T)^{*}$ before $(\mathrm{T}=0 \mathrm{~m})$ and after $(\mathrm{T}=2 \mathrm{~m})$ ingestion of vitamin $A$ in the Senegalese children selected for the surveyt

\begin{tabular}{|c|c|c|c|c|c|c|}
\hline & \multicolumn{6}{|c|}{ No. of children } \\
\hline & \multicolumn{2}{|c|}{$\begin{array}{l}\text { Without or without } \\
\text { ocular infection }\end{array}$} & \multicolumn{2}{|c|}{$\begin{array}{l}\text { With } \\
\text { ocular infection }\end{array}$} & \multicolumn{2}{|c|}{$\begin{array}{l}\text { Without } \\
\text { ocular infection }\end{array}$} \\
\hline & $T=0 \mathrm{~m} \ddagger$ & $T=2 \mathrm{~m} \S$ & $T=0 \mathrm{~m}$ & $T=2 \mathrm{~m}$ & $T=0 \mathrm{~m}$ & $T=2 \mathrm{~m}$ \\
\hline Abnormal & 135 & 75 & 74 & 46 & 61 & 29 \\
\hline Normal & 73 & 110 & 31 & 47 & 42 & 63 \\
\hline Total & 208 & 185 & 105 & 93 & 103 & 92 \\
\hline$x^{2}$ test & \multirow{2}{*}{\multicolumn{2}{|c|}{$\begin{array}{c}23 \cdot 3 \\
0 \cdot 0001\end{array}$}} & \multirow{2}{*}{\multicolumn{2}{|c|}{$\begin{array}{c}9 \cdot 1 \\
0 \cdot 002\end{array}$}} & \multirow{2}{*}{\multicolumn{2}{|c|}{$\begin{array}{c}15.0 \\
0.0001\end{array}$}} \\
\hline $\begin{array}{l}\text { Statistical significance of } \\
T=0 \mathrm{~m} v \cdot T=2 \mathrm{~m}: P<\end{array}$ & & & & & & \\
\hline
\end{tabular}

* For details, see Table 1 and p. 530 .
+ For details of subjects, see pp. $530-531$.
$\$$ ICT was impossible to perform on twelve children during the first examination.
$\$$ ICT was impossible to perform on five children during the second examination.

lead to inaccurate readings (Table 2). It was not possible to perform ICT on twelve children during the first investigation $(T=0 \mathrm{~m})$ and on five children during the second $(T=2 \mathrm{~m})$. After vitamin A ingestion the vitamin A status of the children showed a significant improvement as assessed by cytology, independent of the presence of ocular infection $(P<0.05)$. Of the children with abnormal cytology at $T=0 \mathrm{~m}, 46 \%$ reverted to normal cytology, and $54 \%$ remained abnormal after vitamin A consumption at $T=2 \mathrm{~m}$. Of the children with normal cytological results at $T=0 \mathrm{~m} 90 \cdot 2 \%$ remained normal at $T=2 \mathrm{~m}$ and $9.8 \%$ had abnormal cytology at $T=2 \mathrm{~m}$, after vitamin A consumption.

\section{Biochemical methods}

Serum protein values: RBP and TTR. The protein data are presented in Table 3 . The amount of blood available from each subject was not in all cases sufficient for all the assays. Priority was given to determinations of serum retinol and $\beta$-carotene levels. Therefore, values for serum RBP and TTR are missing for forty-one and twenty-two subjects respectively. Serum levels of RBP and TTR were low and confirmed our previous results (Carlier et al. 1991 b). The majority of the children had RBP and TTR serum levels lower than reference values at both $T=0 \mathrm{~m}$ and $T=2 \mathrm{~m}$ (Vahlquist $e t$ al. 1975). Mean serum RBP and TTR did not differ significantly $(P>0.05)$ before and after consumption of vitamin A.

Serum retinol and $\beta$-carotene values. Table 4 summarizes the biochemical data. There was a significant increase in mean serum retinol levels after ingestion of retinyl palmitate $(P<$ 0.001 ). Retinol deficiency was defined as less than $0.35 \mu \mathrm{mol} / 1$ according to the guidelines of the World Health Organization (1982). Of the subjects $40 \%$ had retinol levels lower than this value $(95 \%$ confidence intervals $(\mathrm{CI}) 33.0,47.0)$ at $T=0 \mathrm{~m}$ and $11.4 \%(95 \% \mathrm{CI} 6.8$, $16 \cdot 0)$ at $T=2 \mathrm{~m}$.

The retinol: RBP molar ratio increased between $T=0 \mathrm{~m}$ and $T=2 \mathrm{~m}$ (Table 4). This increase indicated that the RBP was saturated (Mourey et al. 1990).

$\beta$-carotene serum levels were significantly higher at $T=2 \mathrm{~m}$ than at $T=0 \mathrm{~m}(P<0.001)$. This augmentation was presumably due to mango consumption, although the presence of $\beta$-carotene in the diet was not assessed. 
Table 3. Mean serum retinol-binding protein $(R B P)$ and transthyretin (TTR) levels in the Senegalese children selected for the survey* and percentages of subjects with deficient serum $R B P(\leqslant 26 \mathrm{mg} / \mathrm{l})$ and $T T R(\leqslant 178 \mathrm{mg} / \mathrm{l})$ levels before $(\mathrm{T}=0 \mathrm{~m})$ and after $(\mathrm{T}=2 \mathrm{~m})$ ingestion of vitamin $A$

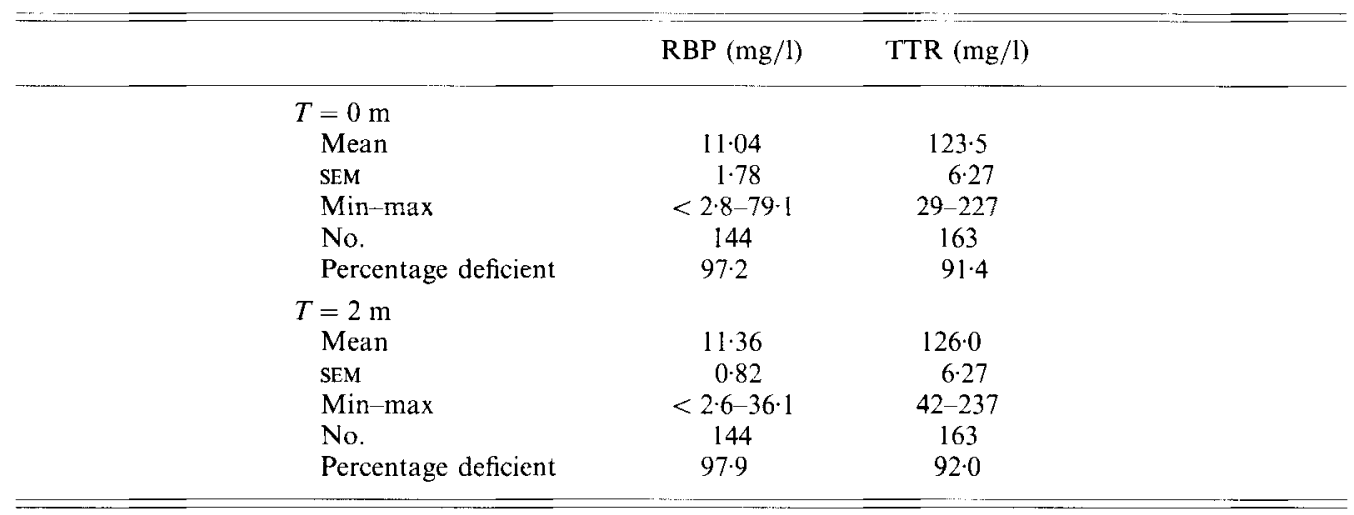

Min-max, minimum-maximum.

* For details of subjects, see pp. 530-531.

Table 4. Mean serum retinol, $\beta$-carotene (n 185) levels and retinol: retinol-binding protein $(R B P)$ molar ratios (n 130) in the Senegalese children selected for the survey $\dagger$ and percentages with deficient $(\leqslant 0.35 \mu \mathrm{mol} / \mathrm{l})$ serum retinol levels before $(\mathrm{T}=0 \mathrm{~m})$ and after $(\mathrm{T}=2 \mathrm{~m})$ ingestion of vitamin $A$

(Mean values with their standard errors)

\begin{tabular}{|c|c|c|c|c|c|c|}
\hline & \multicolumn{2}{|c|}{$\begin{array}{c}\text { Retinol } \\
(\mu \mathrm{mol} / \mathrm{l})\end{array}$} & \multicolumn{2}{|c|}{$\begin{array}{c}\beta \text {-carotene } \\
(\text { nmol } / 1)\end{array}$} & \multicolumn{2}{|c|}{ Retinol: RBP } \\
\hline & Mean & SEM & Mean & SEM & Mean & SEM \\
\hline $\begin{array}{l}T=0 \mathrm{~m} \\
T=2 \mathrm{~m}\end{array}$ & $\begin{array}{l}0.43 \\
0.57^{* * *}\end{array}$ & $\begin{array}{l}0.02 \\
0.02\end{array}$ & $\begin{array}{c}77 \cdot 4 \\
185 \cdot 4^{* * *}\end{array}$ & $\begin{array}{l}14 \cdot 1 \\
49 \cdot 4\end{array}$ & $\begin{array}{l}0.97 \\
1.13^{* * *}\end{array}$ & $\begin{array}{l}0.03 \\
0.02\end{array}$ \\
\hline $\begin{array}{l}\text { Percentage deficient } \\
T=0 \mathrm{~m} \\
T=2 \mathrm{~m}\end{array}$ & $\begin{array}{l}40 \cdot 0 \\
11 \cdot 4\end{array}$ & & & & & \\
\hline
\end{tabular}

*** Mean values were significantly different from those for $T=0 \mathrm{~m}$. (Student's $t$ matched-pairs test): $P<0 \cdot 001$. $\dagger$ For details of subjects, see pp. $530-531$.

Relation between serum vitamin A concentrations and cytology

Children with abnormal eye cytology had lower serum retinol levels (mean 0.39 (SEM 0.02) $\mu \mathrm{mol} / 1$ ) than those with normal eyes (mean 0.48 (SEM 0.03$) \mu \mathrm{mol} / 1 ; P=0.005$ ) at $T=0 \mathrm{~m}$. However, $\beta$-carotene values did not correlate with eye cytological abnormalities at $T=$ $0 \mathrm{~m}$ : means were 72.0 (SEM 14.1) nmol/l for abnormal cytology and 72.0 (SEM 10.6) $\mathrm{nmol} / \mathrm{l}$ for normal cytology.

Four groups were defined according to the cytological changes observed between $T=$ $0 \mathrm{~m}$ and $T=2 \mathrm{~m}$ (Table 5). Mean serum retinol and $\beta$-carotene levels were calculated for each of these four groups (Table 5). After vitamin A ingestion, all the children belonging 
Table 5. Relationship between mean serum retinol (Rol) and $\beta$-carotene $(\beta$-Car) levels and cytological changes in Senegalese children selected for survey $\dagger$

(Mean values with their standard errors)

\begin{tabular}{|c|c|c|c|c|c|c|c|c|c|}
\hline \multirow{3}{*}{$\begin{array}{l}\text { Cytological } \\
\text { changes }\end{array}$} & \multirow{3}{*}{$\begin{array}{l}\text { No. of } \\
\text { childrent }\end{array}$} & \multicolumn{4}{|c|}{$T=0 \mathrm{~m}$} & \multicolumn{4}{|c|}{$T=2 \mathrm{~m}$} \\
\hline & & \multicolumn{2}{|c|}{$\begin{array}{c}\mathrm{Rol} \\
(\mu \mathrm{mol} / \mathrm{l})\end{array}$} & \multicolumn{2}{|c|}{$\begin{array}{c}\beta-\mathrm{Car} \\
(\mathrm{nmol} / \mathrm{l})\end{array}$} & \multicolumn{2}{|c|}{$\begin{array}{c}\text { Rol } \\
(\mu \mathrm{mol} / 1)\end{array}$} & \multicolumn{2}{|c|}{$\begin{array}{c}\beta-\mathrm{Car} \\
(\mathrm{nmol} / 1)\end{array}$} \\
\hline & & Mean & SEM & Mean & SEM & Mean & SEM & Mean & SEM \\
\hline $\begin{array}{c}\text { Group A } \\
\mathrm{AN}(T=0 \mathrm{~m})-\mathrm{AN}(T=2 \mathrm{~m}) \\
\text { Group B }\end{array}$ & 60 & $0 \cdot 42$ & $0 \cdot 04$ & $76 \cdot 7$ & $19 \cdot 7$ & $0 \cdot 53 * * *$ & $0 \cdot 05$ & $127 \cdot 3^{* *}$ & $32 \cdot 4$ \\
\hline $\begin{array}{c}\mathrm{AN}(T=0 \mathrm{~m})-\mathrm{N}(T=2 \mathrm{~m}) \\
\text { Group C }\end{array}$ & 51 & $0 \cdot 37$ & 0.05 & $66 \cdot 6$ & $24 \cdot 3$ & $0.58 * * *$ & 0.05 & $174 \cdot 6^{* * *}$ & $56 \cdot 4$ \\
\hline $\begin{array}{c}\mathrm{N}(T=0 \mathrm{~m})-\mathrm{N}(T=2 \mathrm{~m}) \\
\text { Group } \mathrm{D}\end{array}$ & 55 & $0 \cdot 48$ & $0 \cdot 05$ & $72 \cdot 4$ & $12 \cdot 0$ & $0.60 * * *$ & 0.05 & $284 \cdot 4^{* * *}$ & $148 \cdot 2$ \\
\hline $\mathrm{N}(T=0 \mathrm{~m})-\mathrm{AN}(T=2 \mathrm{~m})$ & 5 & 0.51 & $0 \cdot 15$ & $70 \cdot 2$ & $21 \cdot 1$ & 0.53 & $0 \cdot 18$ & $127 \cdot 8$ & $37 \cdot 0$ \\
\hline
\end{tabular}

AN, abnormal eye cytology; $\mathrm{N}$, normal cytological results; $\mathrm{T}=0 \mathrm{~m}$, baseline (before vitamin $\mathrm{A}$ ); $T=2 \mathrm{~m}, 2$ months after vitamin $\mathrm{A}$.

Mean values were significantly different from those for $T=0 \mathrm{~m}$. (Student's $t$ matched pairs test). ${ }^{* * P}=001$, *** $P=0.001$

+ For details of subjects, see pp. 530-531.

* Fourteen results were missing due to a lack of cytological or blood sampling.

to groups $\mathrm{A}, \mathrm{B}$ and $\mathrm{C}$ showed a significant improvement in their serum retinol and $\beta$ carotene level $(P<0 \cdot 01)$. Serum retinol and $\beta$-carotene levels in those undergoing normal to abnormal changes (group D) did not improve $(P>0.05)$. In spite of this increase in serum vitamin A concentrations, the sixty children of group A still showed abnormal cytology at $T=2 \mathrm{~m}$. The serum retinol and $\beta$-carotene levels of the children with abnormal eye cytology at $T=2 \mathrm{~m}$ were compared with those of the groups with normal eye cytology, at $T=2 \mathrm{~m}$. The abnormal group had significantly lower retinol and $\beta$-carotene levels than the normal group: 0.53 (SEM 0.05) v. 0.59 (SEM 0.03) $\mu \mathrm{mol} / 1(P=0.02)$ and 127.8 (SEM 28.2) v. $232 \cdot 2(\operatorname{SEM} 81 \cdot 1) \mathrm{nmol} / 1(P=0.03)$ respectively.

\section{DISCUSSION}

Efficacy of retinyl palmitate and $\beta$-carotene intake on vitamin A status

Conjunctival cells of the children's eyes with or without ocular inflammation were responsive to vitamin $\mathrm{A}$ administration. However, $54 \%$ of the children who had abnormal cytology remained abnormal after vitamin A ingestion. Furthermore, $9.8 \%$ of the children deteriorated from normal to abnormal 2 months after vitamin A intake. The percentage of children having retinol levels lower than $0.35 \mu \mathrm{mol} / 12$ months after high dose therapy was 11.4 , in spite of hepatic reserves of vitamin A assumed to be more than $20 \mu \mathrm{g} / \mathrm{g}$ liver (approximately $30 \mathrm{mg}$ per liver) which are sufficient to confer protection for about $240 \mathrm{~d}$ (Olson, 1978; West \& Sommer, 1984; Ong \& Amédée-Manesme, 1987; Amédée-Manesme et al. 1988b).

The efficacy of pharmacological doses of vitamin A to maintain elevated serum retinol levels is controversial (Pereira \& Begum, 1971; Thanangkul et al. 1980; Kusin et al. 1980; West \& Sommer, 1984; Thurnham, 1991). Exposure to undernutrition or infection can 
cause the failure of a single oral dose of vitamin A otherwise sufficient for 8-12 weeks. Several studies have shown that moderate undernutrition does not modify the absorption of vitamin A (Reddy \& Sivakumar, 1972; Sivakumar \& Reddy, 1972). The absence of malabsorption could have been demonstrated using the relative dose response test (Amédée-Manesme et al. 1984). However, this test was not performed because the study population was resistant to giving further blood samples.

The relationships between serum vitamin A concentrations and eye cytology were assessed. At baseline, children with abnormal cytology had significantly lower serum retinol values than those with normal cytology. However, no relationship between cytological abnormalities and $\beta$-carotene levels was found. After vitamin A ingestion, the children who had abnormal or normal cytology at baseline showed a significant improvement in their serum retinol and $\beta$-carotene levels $(P<0.01)$, except for the group D (normal to abnormal changes; $P>0.05$ ) In spite of the increase in serum vitamin A concentrations, sixty children of group A remained abnormal. Despite the intake of extra vitamin A, the vitamin A status of the population remained unsatisfactory. This was due to inadequate levels of TTR and RBP, 2 months after vitamin A therapy, presumably due to insufficient dietary protein, particularly essential amino acid-rich protein (Large et al. 1980). The intake of vitamin A has no influence on the release of TTR, which is regulated independently (De Luca et al. 1979). TTR is widely implicated in the inflammatory reaction and its serum levels may, therefore, be considered as a nutritional index only in the absence of inflammation (Ramsden et al. 1978). Proteins of the inflammatory phase were not determined in the present study. However, in our past experience (Carlier et al. 1991 b) the prognostic value of TTR did not seem to be modified by the synthesis of defence factors. There was no significant difference between the proportion of children with low TTR in the non-infected and infected groups. The main amino acid deficiency in cereal diets, such as that eaten by this population, is lysine. In rats, supplementation of a rice diet with lysine restores adequate RBP synthesis (Glover \& Muhilal, 1976). The hepatic reserves of vitamin A were adequate $(30 \mathrm{mg}$; West \& Sommer, 1984) after retinyl palmitate therapy. Thus, satisfactory supply of vitamin A to peripheral targets depends on the availability of particularly RBP and also TTR. In the present study mean serum RBP and TTR concentrations did not differ significantly before and after consumption of vitamin $\mathrm{A}$. These two specific carrier proteins could be the limiting factors for retinol release from the liver and transport in the blood, as a result of the largely cereal and essential amino acidpoor diet of the children (Smith et al. $1973 \mathrm{~b}$ ). Retinyl palmitate may, therefore, lead to only partial cytological improvement due to a lack of retinol-carrier proteins, but dietary $\beta$ carotene may also be involved.

Several investigations showed that almost all children with abnormal cytology reverted to normal after treatment with vitamin A (Wittpenn et al. 1986; Natadisastra et al. 1987; Reddy et al. 1989). The present study is, therefore, inconsistent with previous studies because $54 \%$ of the children with abnormal cytology at $T=0 \mathrm{~m}$ remained abnormal after vitamin A ingestion at $T=2 \mathrm{~m}$ and, furthermore, $9.8 \%$ of the children who had normal cytology at $T=0 \mathrm{~m}$ had abnormal cytology at $T=2 \mathrm{~m}$ after vitamin A consumption.

The validity of the study results could have been affected by the effect of losses to follow up. However, the percentage of children lost during this survey was only $13.6 \%(30 / 220)$, which would not be expected to invalidate the assessment of the efficacy of retinyl palmitate and $\beta$-carotene intake on the vitamin A status of the children (Schwartz, 1986). Biochemical data for assessing vitamin A status were available from fewer children than were cytological data (at $T=0 \mathrm{~m}$; numbers of retinol and RBP serum values and ICT results were 185 and 144 and 208 respectively). This lower number of biochemical data 
could lead to a bias in the before $(T=0 \mathrm{~m})$ and after $(T=2 \mathrm{~m})$ comparisons. Nevertheless, at $T=0 \mathrm{~m}$ children with abnormal eye cytology had lower serum retinol levels than those with normal eyes, and $\beta$-carotene values did not correlate with eye cytological abnormalities. Children with normal cytology had higher serum retinol and also $\beta$-carotene levels than those with abnormal cytology after massive oral doses of vitamin $A$ and consumption of mangoes. Moreover, the ICT test is a reproducible and sensitive method according to the abnormal-normal classification, and is an easy method to perform in the field compared with blood sampling (Thatcher et al. 1977; Carlier, 1991).

Conducting this survey with a placebo or control group would have shown the true efficacy of retinyl palmitate in the treated group and of $\beta$-carotene in the placebo or control group on abnormal to normal cytological change. Consequently, we are now investigating the efficacy of administering doses of $\beta$-carotene which are nutritionally equivalent to those of retinyl palmitate to correct abnormal cytology. Furthermore, the efficacy of mango consumption to prevent vitamin A deficiency will be analysed at the end of the season.

\section{Hypothesis for the possible role of $\beta$-carotene}

Clinical signs of vitamin deficiency were not observed during this investigation, in spite of a high percentage of children having serum retinol values lower than $0.35 \mu \mathrm{mol} / 1(40)$ and abnormal ICT results (64.9). We have previously observed, during a cross-sectional survey ( $n$ 865), that in Senegal very low retinol levels are not correlated with clinical xerophthalmia (Carlier, 1991; Carlier et al. $1991 a, b$ ). This differs from data obtained in Indonesia where the prevalence of biochemical and clinical vitamin A deficiency was as follows: $9 \%$ retinol values under $0.35 \mu \mathrm{mol} / 1$, associated with $1 \%$ Bitot's spot, $0.064 \%$ corneal xerosis and $0.13 \%$ corneal scar (Sommer, 1982). The absence of a relationship between serum retinol and clinical xerophthalmia seems surprising for this region of Senegal. Le François et al. (1981) evaluated the vitamin A status of preschool children in Casamance (south Senegal) by means of clinical and biochemical criteria, but clinical signs of vitamin A deficiency were not detected. In Casamance fruits, vegetables and palm oil are available and consumed almost throughout the year. Although clinical signs of vitamin A deficiency were not detected in preschool children, the percentages of children having retinol and carotenoids levels lower than 0.35 and $720 \mathrm{nmol} / \mathrm{l}$ were 6 and $0 \%$ respectively. There have been a few clinical reports of vitamin A deficiency in African countries where the consumption of carotenoids is high (Casamance, Ivory Coast; Haller \& Lauber, 1980; Le François et al. 1981). Tarwotjo et al. (1982) found that the relative risk of corneal disease was higher in Indonesian children never consuming dark green leafy vegetables than in those consuming them at least once weekly. Children with xerophthalmia were less-frequent consumers of vitamin $\mathrm{A}$ and provitamin A-rich foods than were healthy children, and sources of carotenoids played a major role, differences in stated consumption being confirmed by serum carotene levels. A study in Brazil demonstrated that the consumption of buriti palm (Mauritia vinifera Mart) fruit, which is a rich source of carotenoids, at a daily supplementation of $134 \mu \mathrm{g}$ retinol equivalent for $20 \mathrm{~d}$ was followed by the reversion of clinical and subclinical evidence of vitamin A deficiency (Mariath et al. 1989).

There are more mango trees in the Diourbel region of Senegal than any other type of fruit tree and mango is the most popular fruit for many Senegalese. However, it is difficult to assess total carotenoid intake (Olson, 1980). Investigating the child's dietary intake of mangoes in a quantitative way is difficult because this fruit is not eaten during meals. In addition, the qualitative approach used in the present study does not provide suitable and quantitative information (Olson, 1980). However, the approximate frequency with which the children consumed mangoes was estimated by the mothers to be more than ten mangoes per $d$. Mean serum $\beta$-carotene levels significantly increased (by $140 \%$ ) by June which 
corresponds to the beginning of the mango season and mangoes are the only fruit available at that time of the year. Mangoes are carotenoid-rich, and a large consumption would generate vitamin A stores during the mango season. This may explain the absence of clinical signs of xerophthalmia during the dry season (November-May). The mean serum $\beta$-carotene level increased significantly during the mango season but the serum $\beta$-carotene concentration in children with abnormal cytology was lower than that in children with normal cytology. Napoli \& Race (1988) suggested that the ability of $\beta$-carotene to generate retinoids in tissues, independently of the well-controlled release of retinol from liver, implies that carotenoids with provitamin A activity may have a more extensive role in retinoid homeostasis than has been realized.

It is possible that administering doses of $\beta$-carotene may be an approach preferable to massive oral doses of retinyl palmitate for the elimination of vitamin A deficiency. There has been no report of toxic symptoms or hypervitaminosis resulting from excessive intake of $\beta$-carotene (Hathcock et al. 1990). Napoli \& Race (1988) suggested that $\beta$-carotene could be a source of retinoic acid that is independent of retinol mobilization from liver stores. In undernutrition retinol delivery to peripheral tissues from liver is homeostatically regulated by RBP, whereas carotenoid accumulation in tissues does not seem to be controlled but is directly dependent on serum levels. Future approaches to alleviate the problem of vitamin A deficiency through public health considerations should, therefore, include $\beta$-carotene supplementation. This may involve investigating a variety of issues including high-dose capsules, nutrification, appropriate preservation technologies and horticulture. Above all nutrition education of the populations at risk would be required because $\beta$-carotene is widely distributed among coloured fruits and vegetables which are the principal source of vitamin $\mathrm{A}$ and are often available in developing countries.

The authors gratefully acknowledge the assistance of Pr. B. A. Underwood, Dr. A. Foster, Mr. T. N'Diaye and Mr. M. Fall, and the ORANA institute (Organisme de Recherche en Nutrition et en Alimentation Africaines) in Senegal.

This study was made possible by the collaboration of the following agencies: Ministère de la Coopération Française, Fonds de Recherche de Nestlé Nutrition, Fondation pour le Progrès de l'Homme, Fondation Voir et Vivre, Fondation Raoul Follereau, Fondation Enfants de la Terre, Société Behring, Roche France et le Département de Sciences et de Technologie pour le développement de la Communauté Economique Européenne no. TS $2232 \mathrm{~F}$.

\section{REFERENCES}

Amédée-Manesme, O., Anderson, D. \& Olson, J. A. (1984). Relation of the relative dose response test to liver concentrations of vitamin A in generally well nourished surgical patients. American Journal of Clinical Nutrition 39, 898-902.

Amédée-Manesme, O., Luzeau, R., Carlier, C. \& Ellrodt, A. (1987). Simple impression cytology method for detecting vitamin A deficiency. Lancet i, 1263.

Amédée-Manesme, O., Luzeau, R., Wittpenn, J. R., Hanck, A. \& Sommer, A. (1988a). Impression cytology detects subclinical vitamin A deficiency. American Journal of Clinical Nutrition 47, 875-878.

Amédée-Manesme, O., Mourey, M. S., Couturier, M., Lemonnier, F., Hanck, A.\& Allagille, D. (1988b). Shortand long-term vitamin A treatment in children with chronic cholestasis. American Journal of Clinical Nutrition 47, $690-693$.

Carlier, C. (1991). L'impression oculaire transférée: une nouvelle méthode de diagnostique du déficit en vitamine A. PhD Thesis, University of Jussieu, Paris, France.

Carlier, C. \& Amédée-Manesme, O. (1991). Impression cytology with transfer: a novel nutritional index. Journal of Pediatric Gastroenterology and Nutrition 90, 9359.

Carlier, C., Mourey, M. S., Luzeau, R., Lemonnier, D. \& Amédée-Manesme, O. (1989). Assessment of vitamin A status in an elderly French population using impression cytology with transfer. International Journal for Vitamin and Nutrition Research 59, 3-7.

Carlier, C., Moulia-Pelat, J. P., Ceccon, J. F., Mourey, M. S., Fall, M., N'Diaye, A. M.\& Amédée-Manesme, O. 
(1991 a). Prevalence of malnutrition and vitamin A deficiency in the Diourbel, Fatick and Kaolack regions of Senegal. Epidemiological study. American Journal of Clinical Nutrition 53, 70-73.

Carlier, C., Moulia-Pelat, J. P., Ceccon, J. F., Mourey, M. S., Malvy, D., Fall, M., N'Diaye, A. M. \& AmédéeManesme, O. (1991b). Prevalence of malnutrition and vitamin A deficiency in the Diourbel, Fatick and Kaolack regions of Senegal. Controlled study. American Journal of Clinical Nutrition 53, 74-77.

De Luca, L. M., Glover, J., Heller, J., Olson, J. A. \& Underwood, B. A. (1979). Recent Advances in the Metabolism and Function of Vitamin A and their Relationship to Applied Nutrition. Washington, DC: International Vitamin A Consultative Group, Nutrition Foundation.

Fink, P. C., Romer, M., Haechkel, R., Fateh-Moghdam, A. \& Delauche, J. (1989). Measurement of proteins with the Behring nephelemeter. A multicenter evaluation. Journal of Clinical and Biochemical Chemistry 27, $261-276$.

Glover, G. \& Muhilal. (1976). Nutritional factors affecting the biosynthesis of retinol-binding protein in the liver and its release into the plasma. International Journal for Vitamin and Nutrition Research 46, 239-243.

Glover, J. (1983). Factors affecting vitamin A transport in animals and man. Proceedings of the Nutrition Society 42, 19-30.

Goodman, D. S. (1984). Plasma retinol-binding protein. In The Retinoids, vol. 2, pp. 41-88 [M. B. Sporn, A. B. Roberts and D. S. Goodman, editors]. New York: Academic Press.

Haller, L. \& Lauber, E. (1980). Santé de l'enfant d'âge scolaire en Côte d'lvoire (Health status of school-age children in the Ivory Coast). Acta Tropica 37, Suppl. 11.

Hathcock, J. N., Hattan, D. G., Jenkins, M. Y., McDonald, J. T., Ramnathan Sundaresan, P. \& Wilkening, V. L. (1990). Evaluation of vitamin A toxicity. American Journal of Clinical Nutrition 52, 183-202.

Ingenbleek, Y., Van Den Schrieck, H. G., De Nayer, P. \& De Visscher, M. (1975). The role of retinol-binding protein in protein-calorie malnutrition. Metabolism 24, 633-641.

Kanai, M., Raz, A. \& Goodman, D. S. (1986). Retinol-binding protein: the transport protein for vitamin A in human plasma. Journal of Clinical Investigation 47, 2025-2044.

Keenum, D. G., Semba, R., Wirasasmita, S., Natadisastra, G., Muhilal, West, K. P. \& Sommer, A. (1990). Assessment of vitamin A status by a disk applicator for conjunctival impression cytology. Archives of Ophthalmology 108, 1436-1441.

Kusin, J. A., Sinaga, H. S. R. P. \& Smit, E. M. (1980). Vitamin A status of preschool children in Suka village, North Sumatra after an oral massive dose. Meeting on Vitamin A Deficiency and Xerophthalmia. NUT/80. Jakarta: WHO.

Large, S., Neal, G., Glover, J., Thanangkul, O. \& Olson, R. E. (1980). The early changes of retinol-binding protein and prealbumin concentrations in plasma of protein-energy malnourished children after treatment with retino] and an improved diet. British Journal of Nutrition 43, 393-402.

Le François, P., Chevassus Agnès, S., Benefice, E., Dyck, J. L., Maire, B., Parent, G., Seymat, G. \& N'Diaye, M. (1981). Etat vitaminique A de populations dans trois pays de l'Afrique de l'Ouest (Vitamin A status of populations in three West African countries). Bulletin de COrganisation de Coopération et de Coordination des Grandes Endémies 73, $50-61$.

Luzeau, R., Carlier, C., Ellrodt, A. \& Amédée-Manesme, O. (1988). Impression cytology with transfer: an easy method for detection of vitamin A deficiency. International Journal for Vitamin and Nutrition Research 58, 166-170.

Matiath, J. G. R., Lima, M. C. C. \& Santos, L. M. P. (1989). Vitamin A activity of buriti (Mauritia vinifera Mart) and its effectiveness in the treatment and prevention of xerophthalmia. American Journal of Clinical Nutrition 49. 849-853.

Moore, T. (1957). Vitamin A, pp. 3-16. New York: Elsevier.

Mourey, M. S., Siegenthaler, G. \& Amédée-Manesme, O. (1990). Regulation of metabolism of retinol-binding protein in children with biliary atresia. American Journal of Clinical Nutrition 51, 638-643.

Napoli, J. L. \& Race, K. R. (1988). Biogenesis of retinoic acid from / 3 -carotene. Journal of Biology and Chemistry 263, 1737217377.

Natadisastra, G., Wittpenn, J. R., West, K. P., Muhilal \& Sommer, A. (1987). Impression cytology for detection of vitamin A deficiency. Archives of Ophthalmology 105, 1224-1228.

Olson, J. A. (1978). Evaluation of vitamin A status in children. World Review of Nutrition and Dietetics 31, $130-134$

Olson, J. A. (1980). Evaluation of vitamin A status in individuals and populations. Philippines Journal of Nutrition 3, $2 \cdots 10$.

Ong, D. \& Amédée-Manesme, O. (1987). Cellular retinol-binding protein and vitamin A status of patients with biliary atresia. Hepatology $7,253-256$.

Oomen, H. A. P. C. (1954). Xerophthalmia in the presence of kwashiorkor. British Journal of Nutrition $\mathbf{8}, 307$.

Pereira, S. M. \& Begum, A. (1971). Failure of a massive single oral dose of vitamin A to prevent deficiency. Archives of Disease in Childhood 46, 525.

Ramsden, R. B., Prince, H. P., Burr, W. A., Bradwell, A. R., Black, E. G., Evans, A. \& Hoffenberg, R. (1978). The interrelationship of thyroid hormones, vitamin $\mathrm{A}$ and their binding proteins following acute stress. Clinical Endocrinology 8, 109-122.

Reddy, V., Rao, V., Reddy, A. M. (1989). Conjunctival impression cytology for assessment of vitamin A status. American Journal of Clinical Nutrition 50, 814-817. 
Reddy, V. \& Sivakumar, B. (1972). Studies on vitamin A absorption in children. Indian Pediatrics 9, 307-310.

Schwartz, D. (1986). Méthodes statistiques à lusage des médecins et des biologistes. 3rd ed. Paris: Flammarion Médecine-Sciences.

Sivakumar, B. \& Reddy, V. (1972). Absorption of labelled vitamin A in children during infection. British Journal of Nutrition 27, 299-304.

Smith, F. R., Goodman, D. S., Arroyave, G. \& Viteri, F. (1973a). Serum albumin, retinol-binding protein and prealbumin concentrations in protein-calorie malnutrition. II. Treatment including supplemental vitamin $\mathrm{A}$. American Journal of Clinical Nutrition 26, 982-987.

Smith, F. R., Goodman, D. S., Zaklama, M. S., Gabr, M. K., Maraghy, S. \& Patwardhan, V. S. (1973b). Serum vitamin A, retinol-binding protein and prealbumin concentrations in protein-calorie malnutrition. I, A functional defect in hepatic retinol release. American Journal of Clinical Nutrition 26, 973-981.

Sommer, A. (1982). Field Guide to the Detection and Control of Xerophthalmia, 2nd ed. Geneva: WHO.

Sommer, A., Quesada, J., Doty, M. \& Faich, G. (1975). Xerophthalmia and anterior-segment blindness among preschool-age children in El Salvador. American Journal of Ophthalmology 80, 1066.

Tarwotjo, I., Sommer, A., Soegiharto, T., Susanto, D. \& Muhilal. (1982). Dietary practices and xerophthalmia among Indonesian children. American Journal of Clinical Nutrition 35, 574-581.

Thanangkul, O., Promkutkaew, C., Waniyapong, T. \& Damrongsak, D. (1980). Comparison of the effects of a single high dose of vitamin A given to mother and infant upon plasma levels of vitamin $\mathrm{A}$ in the infant. Meeting on Vitamin A Deficiency and Xerophthalmia. NUT/WP/74.14. Jakarta: WHO.

Thatcher, R. W., Darougar, S. \& Jones, B. (1977). Conjunctival impression cytology. Archives of Ophthalmology 95, 678-681.

Thurnham, D. I. (1991). Vitamin A and childhood mortality. Lancet 337, 232.

Thylefors, B., Dawson, C. R., Jones, B. R., West, S. K. \& Taylor, H. R. (1987). A simple system for the assessment of trachoma and its complications. Bulletin of the World Healh Organization 65, 477-483.

Tsou, S. C. S., Gershon, J., Simpson, K. L. \& Chichester, C. O. (1984). Promoting household gardens for nutrition improvement. In Human Nutrition, Better Nutrition, Better Life. Proceedings 4th Asian Congress of Nutrition, [V. Tanphaichitri, V. Dahlan, V. Suphakarn and A. Valyavesi, editors]. Bangkok: Aksornsmai Press.

Vahlquist, A., Rask, L., Peterson, P. A. \& Berg, T. (1975). The concentrations of retinol-binding proteins, prealbumin and transferrin in the sera of newly delivered mothers and children of various ages. Scandinavian Journal of Clinical and Laboratory Investigation 35, 569-575.

Waterlow, J. C. (1976). Classification and definition of protein-energy malnutrition. In Nutrition in Preventive Medicine. Technical Report Series no. 62, pp. 530-555 [G. H. Beaton and J. M. Bengoa, editors]. Geneva: WHO.

West, K. P. \& Sommer, A. (1984). Periodic, Large Oral Doses of Vitamin A for the Prevention of Vitamin A Deficiency and Xerophthalmia: A Summary of Experiences A Report of the International Vitamin A Consultative Group (IVAGC). Washington, DC: The Nutrition Foundation.

Wittpenn, J. R., Scheffer, C., Tseng, G. \& Sommer, A. (1986). Detection of early xerophthalmia by impression cytology. Archives of Ophthalmology 104, 237-239.

Wolbach, S. B. \& Howe, P. R. (1925). Tissue changes following deprivation of fat-soluble A vitamin. Journal of Experimental Medicine 42, 753-777.

World Health Organization (1982). Control of vitamin A deficiency and Xerophthalmia. Report of a joint WHO/UNICEF/USAID/Helen Keller International/IVAGC meeting. Technical Report Series no. 672. Geneva: WHO.

World Health Organization (1983). Measuring Change in Nutritional Status. Geneva: WHO. 